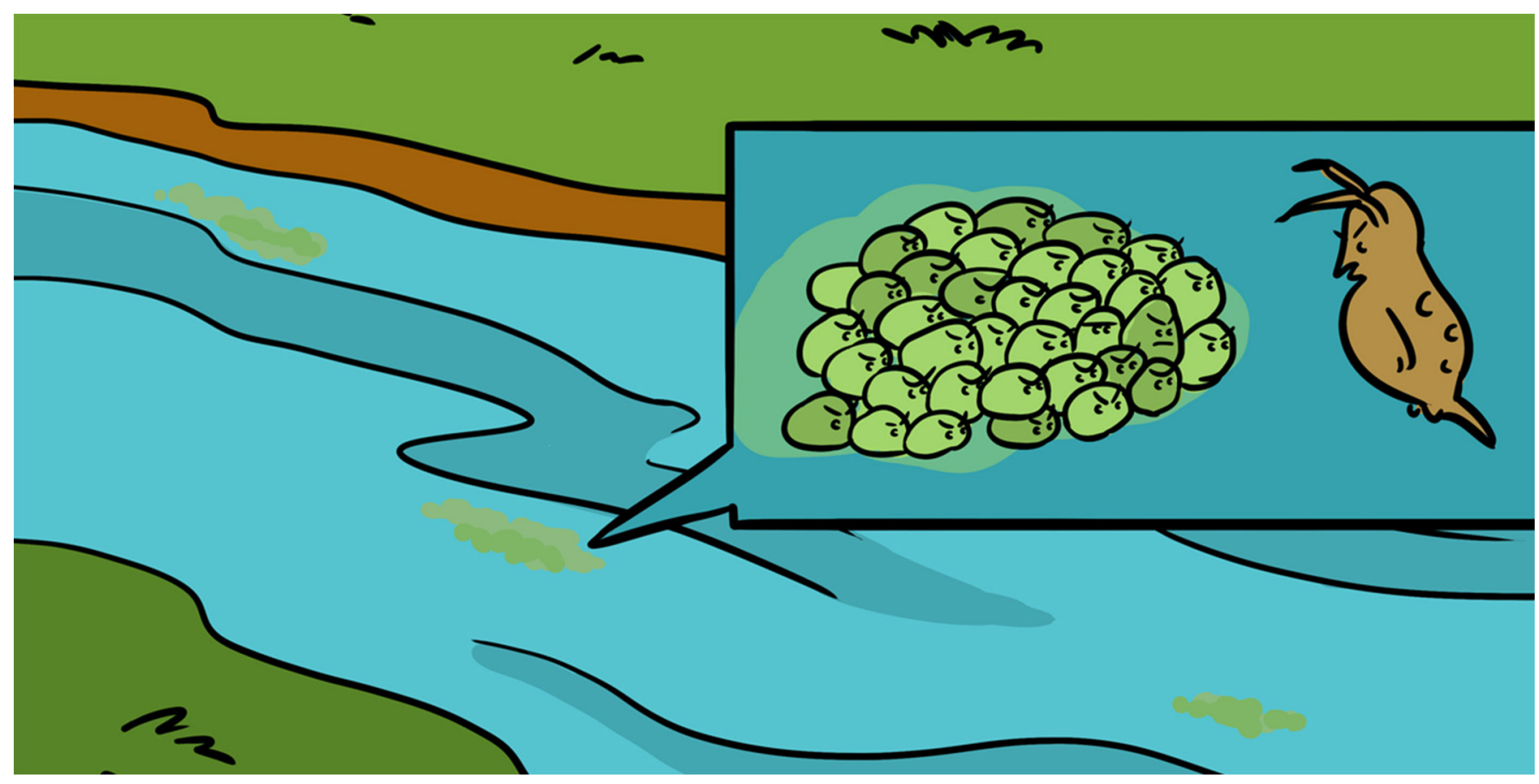

\title{
GREEN BLOBS AND PREDATORY BEASTS: CLUES TO MULTICELLULARITY
}

\section{Stefania E. Kapsetaki ${ }^{1 *}$, Roberta M. Fisher ${ }^{2}$ and Stuart A. West ${ }^{1}$}

${ }^{1}$ Department of Zoology, University of Oxford, Oxford, United Kingdom

2 Section of Ecology and Evolution, University of Copenhagen, Copenhagen, Denmark

\section{YOUNG REVIEWER:}

$\begin{array}{lll} & \text { JEDIDIAH } \\ 3 & \text { AGE: } 13\end{array}$

\section{MULTICELLULAR}

A group of three or more cells in cell-cell contact.
Look at your reflection in the water. What do you see? Look closer, closer, and even closer. You are in fact made up of trillions of cells. But you were not always like this. Come on a journey back in time, to the depths of our existence, and we will show you how predatory beasts may have affected your evolutionary history, leading to trillions of cells helping each other, trapped inside a creature. You!

\section{BACK IN TIME ...}

Almost 3.5 billion years ago, before humans, trees, and even dinosaurs, the only living things on Earth were single cells. As the years passed by, these cells reproduced, divided over and over again and filled the planet with lots of single cells. They lived on land and in the sea, but they stayed really small for millions and millions of years.

But then all of a sudden, creatures made up of many cells started to appear. Today we see these "multicellular" species all around us. Just 


\section{PREDATOR}

An organism that obtains food by killing and consuming other organisms.

\section{COOPERATION}

An action that provides a benefit to another individual (recipient), and the evolution of which has been dependent on its beneficial effect for the recipient.

\section{Figure 1}

Algae and predators. The three different algae species $(\mathbf{A}-\mathbf{C})$ and predators (D-F) used in this study. The scale is indicated at the top. A $\mu \mathrm{m}$ is $1 / 1,000$ of a $\mathrm{mm}$. Reproduced from the original publication [5]. look around you - there are cats and dogs, horses, lizards, mushrooms, and trees. You can even see them when you look at your reflection ... the world is full of them.

But wait, in the beginning of time there were simply single-celled creatures and then, suddenly, they became multicellular creatures? What? What happened? What makes single cells form a multicellular creature?

\section{DID YOU KNOW CELLS CAN BE SOCIAL?}

Sometimes cells live all on their own. In fact, most of the species living on the planet right now are just single cells, but they are so small that we cannot see them. These single-celled organisms include bacteria that you can find on dirty hands and algae that you find in rivers. But, these cells can also live together in groups that can help them survive [1]. They can communicate with each other, just like we do, and also help each other to find food, defend against predators, and to reproduce [2-4]. When they help each other, we call this cooperation.

\section{DO CELLS FORM GROUPS WHEN PREDATORS ARE AROUND?}

If there is a predator around, a cell may help another cell by sticking to it and forming a group. This group may be too big for the predator to

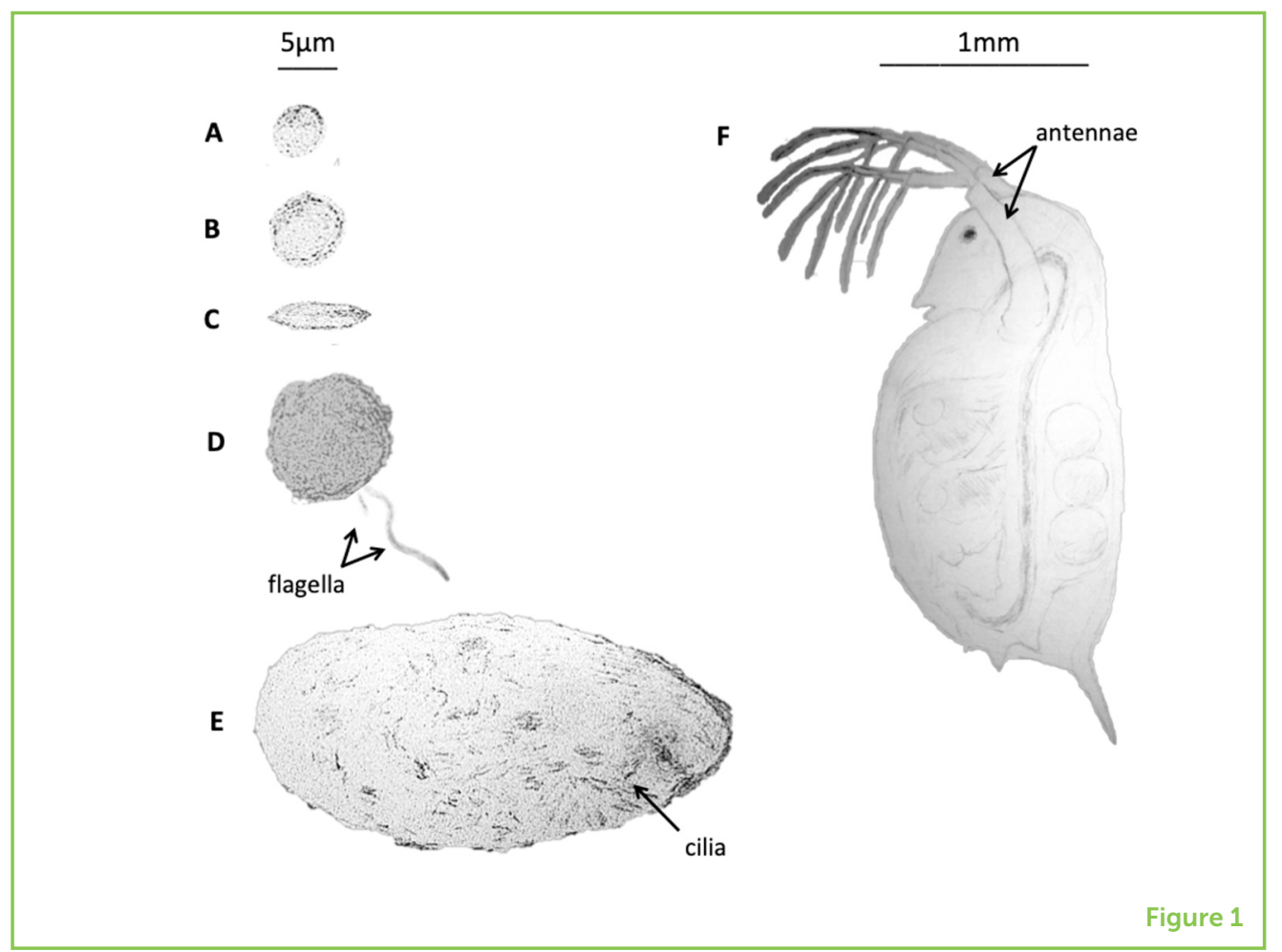


eat-like a tiger trying to eat an elephant! In this way, the cells in the group may protect themselves from being eaten.

We did an experiment to see whether this could be true. We tested whether single cells form groups when there are predators around. Previous studies hinted that predatory beasts and single-celled algae that live in rivers and ponds might be a good model system. So we added three different predators (Figures 1D-F), to three different algae (Figures $1 \mathrm{~A}-\mathrm{C}$ ). These algae do not have any "legs," so they are known as immobile. Whereas, these predators have "legs" and they are mobile. For example, one predator (Figure 1D) has long and short "legs" called flagella. The other predator (Figure 1E) has around 500 "legs" on its surface, called cilia. And the largest of the three predators (Figure 1F) can move its antennae and even its whole body.

When we added each of these predators to our algae, we saw that the algae always grouped together. Sometimes we could even see the groups with the naked eye (Figure 2). What was even cooler was that these multicellular groups appeared in all kinds of different shapes and sizes (Figure 3).

Some of you may have already spotted a problem in this experiment. How do we know whether the algae themselves formed a group, whether the movement of the predator caused this grouping, or even if the predator ate the single cells and left the groups in the liquid? To answer this question, we took liquid from the predator culture and squeezed it through a device that removed the cells and big chemicals. All that passed through was lots of tiny molecules - the waste products, or the "poo," of the predators. We added these tiny molecules to the algae, and saw that sometimes the algae still formed multicellular groups. This told us that sometimes algae form groups when they think predators are around. The groups even break apart when they realize that there is not a predator around.

Figure 2

Algae group together in response to predators. In tube A, we did not expose the algae to the predator. In tube B, we exposed the algae to the predator. We see that the algae formed groups in tube B in response to the predator (in the white circles). Reproduced from the original publication [5].

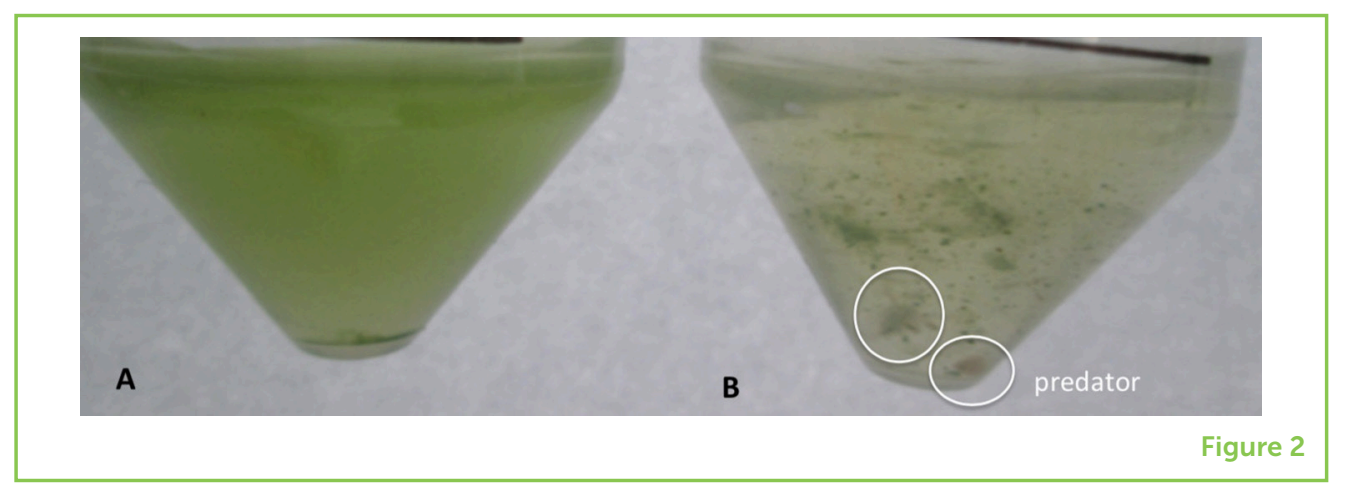




\section{Figure 3}

Examples of groups formed by algae in our experiments. (A, D) 3-celled group (B, C, E) 4-celled groups. The scale is shown in the lower right corner. Reproduced from the original publication [5].
A

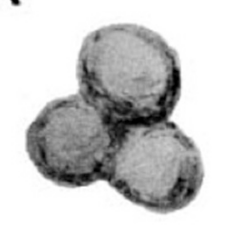

B
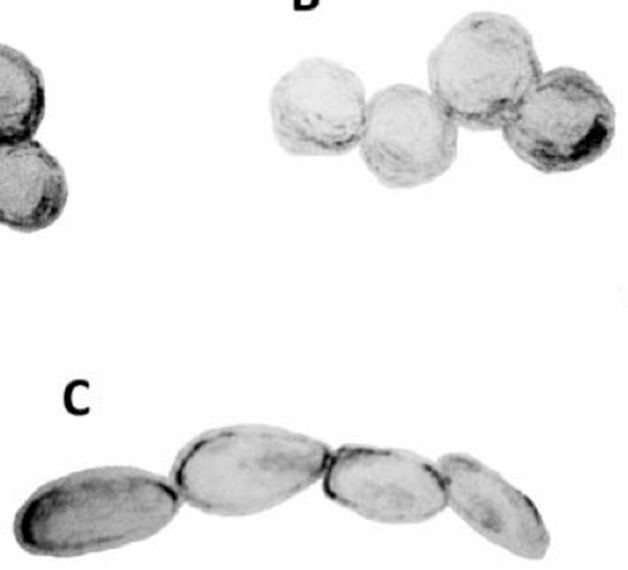

D

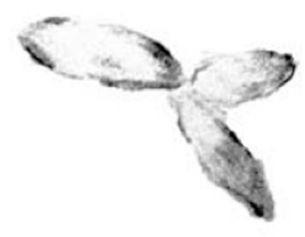

E

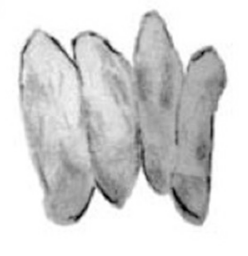

$5 \mu \mathrm{m}$

\section{SOME OPEN QUESTIONS ABOUT MULTICELLULARITY}

You may be asking why the algae form groups in response to predators. Are groups protected from being eaten by the predator? Or do they still get eaten? Can they survive inside the predator's tummy? We have exciting results to share with you in our next publication. It is coming out soon, so stay tuned!

\section{ACKNOWLEDGMENTS}

We thank the European Research Council, the Natural Environment Research Council, the State Scholarships Foundation of Greece, the Alexander S. Onassis Public Benefit Foundation Scholarship, and A. G. Leventis Foundation Scholarship for funding the research conducted in the original publication [5]. 


\section{ORIGINAL SOURCE ARTICLE}

Kapsetaki, S. E., Fisher, R. M., and West, S. A. 2016. Predation and the formation of multicellular groups in algae. Evol. Ecol. Res. 17:651-69. Available online at: http://zoo-web02.zoo.ox.ac.uk/group/west/pdf/Kapsetaki_etal_16.pdf

\section{REFERENCES}

1. West, S. A., Fisher, R. M., Gardner, A., and Kiers, E. T. 2015. Major evolutionary transitions in individuality. Proc. Natl. Acad. Sci. U.S.A. 112:10112-9. doi: 10.1073/pnas.1421402112

2. Grosberg, R. K., and Strathmann, R. R. 2007. The evolution of multicellularity: a minor major transition? Annu. Rev. Ecol. Evol. S 38:621-54. doi: 10.1146/ annurev.ecolsys.36.102403.114735

3. Koschwanez, J. H., Foster, K. R., and Murray, A. W. 2013. Improved use of a public good selects for the evolution of undifferentiated multicellularity. eLife 2:e00367. doi: 10.7554/eLife.00367.001

4. Smith, J., Queller, D. C., and Strassmann, J. E. 2014. Fruiting bodies of the social amoeba Dictyostelium discoideum increase spore transport by Drosophila. BMC Evol. Biol. 14:105. doi: 10.1186/1471-2148-14-105

5. Kapsetaki, S. E., Fisher, R. M., and West, S. A. 2016. Predation and the formation of multicellular groups in algae. Evol. Ecol. Res. 17:651-69. Available online at: http://zoo-web02.zoo.ox.ac.uk/group/west/pdf/Kapsetaki_etal_16.pdf

SUBMITTED: 28 September 2018; ACCEPTED: 28 January 2019; PUBLISHED ONLINE: 15 February 2019.

EDITED BY: Phillip R. Myer, The University of Tennessee, Knoxville, United States

CITATION: Kapsetaki SE, Fisher RM and West SA (2019) Green Blobs and Predatory Beasts: Clues to Multicellularity. Front. Young Minds 7:20. doi: 10.3389/frym.2019.00020

CONFLICT OF INTEREST STATEMENT: The authors declare that the research was conducted in the absence of any commercial or financial relationships that could be construed as a potential conflict of interest.

COPYRIGHT @ 2019 Kapsetaki, Fisher and West. This is an open-access article distributed under the terms of the Creative Commons Attribution License (CC BY). The use, distribution or reproduction in other forums is permitted, provided the original author(s) and the copyright owner(s) are credited and that the original publication in this journal is cited, in accordance with accepted academic practice. No use, distribution or reproduction is permitted which does not comply with these terms. 


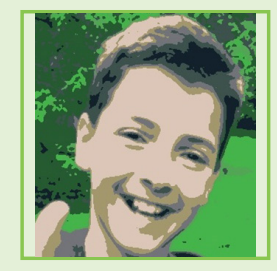

\section{YOUNG REVIEWER}

\section{JEDIDIAH, AGE: 13}

I am interested in Science and Math, particularly in how the environment impacts my daily life. I spend time working in the family garden, making money by selling eggs and vegetables I help produce. In my spare time, I like to play baseball and play video games.

\section{AUTHORS}

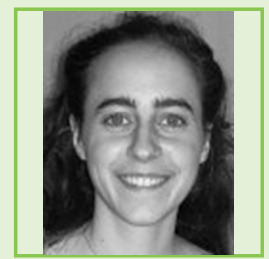

\section{STEFANIA E. KAPSETAKI}

I am a Ph.D. student at the Department of Zoology at the University of Oxford. My project is focused on the evolution of multicellularity in algae (https://scholar.google. com/citations? user=Jp5vnH8AAAAJ\&hl=en). *stkapsetaki@gmail.com

\section{ROBERTA M. FISHER}

I am a post-doc at Copenhagen University. I am interested in how and why multicellular organisms evolve. Sometimes I also do experiments using algae and yeast to try and evolve multicellularity in the lab! (https://scholar.google.co.uk/citations? use $r=a S d P t 7 Y A A A A J g h l=e n)$.

\section{STUART A. WEST}

I am a Professor of Evolutionary Biology at the University of Oxford. My work is mainly focused on adaptation, and especially the evolution of social behaviors. (https://scholar.google.com/citations?user=WkrOMEoAAAAJghl=en). 